\title{
огляди
}

\section{BIOCHEMICAL EFFECTS OF ESTROGENS IN NON-REPRODUCTIVE ORGANS}

\author{
A. S. MIKOSHA, E. I. KOVZUN, N. D. TRONKO \\ State Institution V. P. Komisarenko Institute of Endocrinology and Metabolism, \\ National Academy of Medical Sciences of Ukraine, Kyiv; \\ e-mail: asmikosha@gmail.com
}

Biochemical processes initiated by estrogenic hormones in the organs which are not directly related to reproduction were described in the survey on the basis of literature and the authors' own studies. The importance of these compounds in the regulation of fundamental biological processes has been established in the last decades. The biochemical mechanisms of realization of estrogen effects may be considered as potential links of pathogenesis for a number of diseases and as targets of their therapy.

Key words: estrogens, biochemical mechanisms, non-reproductive organs, endocrine glands, brain, cardiovascular system.

$\mathrm{E}$ strogenic hormones have been considered for decades only as regulators of sexual functions. But the facts have been accumulated, which evidence for the extreme importance of these compounds for the whole organism regardless of its genetic belonging to males or females. The work purpose is a brief survey of bichemical processes with participation of estrogens in the organs apart from the reproductive system.

Estrogens play the important part in regulation of physiological processes as well as in aging and pathology. Investigations have shown a fundamental role of estrogens in the activity of reproductive, cardiovascular, muscular, bone, nervous systems as well as in development of pathology in these systems, in oncopathology, in particular. Biochemical effects of estrogens are displayed both in genetically female and male organisms, though the character and expression of the effects may be essentially different. Estrogens are formed in the male organism in the adrenal cortex and testicles; transformation of testosteron and androstenedione by aromatase into estrogen in many tissues, in the fatty tissue, in particular, serves as the additional and maybe even the major source of estrogens in a quantitative sense [1]. The amount of synthesized estradiol (E2) increases in men with the growth of the mass of fatty tissue.

\section{Characteristic of fundamental processes of estrogens effect}

The basic mechanisms of the effect of these hormones have been deciphered by the efforts of biochemists and molecular biologists. Two main ways to realize their effect have been shown: genome and non-genome ones.

The genome way begins by coupling the estrogen molecules with nucleus receptors. Receptors of two types $\alpha$ and $\beta$ have been found and studied. They are rather close as to their amino acid composition, coincide partially by physiological functions and distribution in tissues, but a number of effects realized with the help of these estrogenic receptors (ER) differs. These differences could be especially distinctly established, using the knock-out methodology. In particular, complete infertility and disturbance of sexual behaviour are observed in male mice deprived of ER $\alpha$. No fertility disturbances were observed in males under ER $\beta$ knock-out [2]. Splicing variants of ER are also known which probably possess certain biological activity as well, but they are poorly studied.

ER genes were mapped, and it was shown that ER $\alpha$ is in a long chromosome 6 arm, while gene ER $\beta$ is in chromosome 14q 22-24 [3-6]. The expression of $\mathrm{ER} \alpha$ and $\mathrm{ER} \beta$ differs [7]. ER $\alpha$ is expressed intensive- 
ly in the uterus, testicles, hypophysis and mammary glands, while ER $\beta$ is expressed to a higher extent in the brain, prostate, ovaries, lungs and adrenals $[7,8]$. The expression of receptors is not interrelated.

Estrogen receptors are among the superfamily of nuclear hormonal receptors. ER $\alpha$ contains 595 amino acids [3], and ER $\beta$ - 530 amino acids [4]. Nuclear receptors of estrogens contain 6 functional domains [9].

Domains A and B being on the $\mathrm{N}$-end are the most variable sites of the receptor, and isoforms $\alpha$ and $\beta$ contain no more than $20 \%$ of homologic amino acids. A/B domains can activate the transcription even without binding to ligand (AF-1). This function is specific to cells of various types and differs from the transcription activator AF-2, located in domain $E$ [10]. The central domain $C$ ensures the receptor binding to DNA and dimerization. It is highly conservative: $95 \%$ of amino acids of $\alpha$ - and $\beta$-isoforms coincide. A highly conservative site of binding to DNA has 2 zinc digits, and that ensures ER contact with DNA. Domain D forms a loop. The domain is rather variable: homology does not exceed $30 \%$ and determine nuclear localization. Domain E binds a ligand and performs the activating function (AF-2). It is also responsible for the receptor dimerization. Conservativeness reaches $59 \%$. The function of $\mathrm{F}$ domain is insufficiently studied; homology of $\alpha$ и $\beta$ isoforms does not exceed $20 \%$.

ER activity is regulated by a number of cofactors, which can: 1) change affinity and specificity of binding; 2) interact with other regulatory and transcriptional factors; 3) remodel nucleosomal/chromatin structure.

In the absence of ligands the estrogenic receptor is not active in the nucleus and connected with cell chaperons, such as the heat shock proteins (HSP90). In the presence of ligand the estrogenic receptor gets rid of chaperons and is activated. Activated ER is phosphorylated and bound in a form of a homodimer or heterodimer with estrogen-responsible element (ERE) of the promotor site of the target genes. ERE is a palindrome sequence 5'-GGTCAnnnTGACC-3' in DNA [11]. A spacer site nnn can contain various bases and their number may exceed three. Some details of ERE structure and its interaction with ER are generalized in the survey by Gruber and co-authors [12].

AF-1 and AF-2 domains function with participation of co-activators - cell proteins facilitate transcription. They belong to various groups: coactivators of steroid receptors (SRC/P160); CREBbinding proteins (CBP); coactivator-associated arginine methyltransferase 1 (CARM1). Structures of these co-activators are different and they promote the transcription in different ways - acetylating histones, methylating them or by ubiquitinylation [13].

An important role of actin and its relative proteins in performing the transcription has been elucidated in the recent years [14]. It appeared that actinine-4 (ACTN4) takes part in realization of transcription activity of ER $\alpha$. ACTN4 and its splicing variant interact with GRIP1 (protein interacting with glucocorticoid receptor) and PCAF (a factor bound to $\mathrm{p} 300 / \mathrm{CBP}$ ) and regulate the transcription mediated by ER $\alpha$ [14].

A lot of facts have been accumulated indicating that a paradigm of ER binding to ERE limits essentially the understanding of mechanisms of ER effect on the transcription. It is known that some enhancers include only a half of ERE palindrom, while the second half is at a considerable distance [15]. Most genes contain no ERE but are activated by ER. In some cases ER bind to other transcription factors and interact with DNA through these factors.

The intracellular distribution of ER has been studied. It appears that receptors are present in the plasmatic membranes, cytosole and nuclei [16]. The membrane receptors cannot activate the transcription, but can induce phosphorylation of mitogenactivated proteinkinase (MAPK) when binding to estradiol. It was later shown that the receptors of another structure are also present in membranes; they transfer the estrogen signals which are not connected with the transcription and genome $[17,18]$. These nonclassical receptors are connected with Gproteins and are transmembrane receptors. A quick effect under these receptors liganding includes the release of intracellular $\mathrm{Ca}^{2+}$ and subsequent activation of Ca-calmoduline kinases or activation of MAPK or PI3-kinase pathways. This type of receptors was primarily called GPR30, but nowadays it is often called GPER, or GPER1. It appeared that besides plasmatic membranes, which are usually considered as the site of G-receptors distribution, it is also present in intracellular membranes [19]. The modern data on GPER function in norm and pathology are generalized in the survey by Prossnitz [20], while the survey by Srivastava summarizes the data on its role in the nervous system [21]. 


\section{Role of estrogens in physiology and pathophysiology of the brain and cardio-vascular system}

The discussion of fundamental aspects of this problem became the content of a special issue of the J. Mol. Cell Endocrinol. in May 2014.

Numerous investigations have shown that estrogens take an important trophic and protective part in the brain. Epidemiological data show that the estrogen replacement therapy in women in menopause favors the improvement of some indications of cognitive processes, protects from cognitive disturbances and decreases incidence of Alzheimer disease [22, 23]. Estrogens decrease mortality and expression of pathologic changes under stroke $[24,25]$. However, some researchers did not observe positive effects when using estrogens. Possible causes are shown in the work by Suzuki and Brown on mice [26]. They have found that E2 takes a protective effect under stroke injury, if it is used immediately after ovariectomy. Ten weeks after the operation the administration of E2 is inefficient. The long-term hypoestrogeny disturbs neuroprotective and anti-inflammatory effects of E2.

Transcriptome of the cerebral cortex was studied on ovariectomized mice which were implanted a silastic tubing ensuring physiological level of E2. Change of the transcription level of 88 genes was revealed after 7 days in the animals which received E2 as compared with castrated ones [27]. Functions of these genes are connected with cerebro-vascular system, growth of neurons and tissue homeostasis.

A lot of biochemical mechanisms participating in realization of the effect of estrogens in physiological and pathophysiological processes which proceed in nervous tissues have been described. Some of these mechanisms are generalized in the surveys [28-31].

Neuroprotective effect of estrogens on the cell level was shown on a whole number of models. In particular, the protective effect of estradiol in vitro under the influence of $\beta$-amyloid and glutamate is shown $[32,33]$. MAPK activation by estrogen receptor is required for protection from $\beta$-amyloid [32]. It has been established that ER expression is necessary for neurons protection from the toxical effect of glutamate [34]. The protective effect is realized both with ERE participation in gene promotor and through activation of MAPK-pathway.
Estradiol takes the neuroprotective effect under excitotoxic injuries. This effect is realized through the increase of the level of glutamate transporters expression in astrocytes, mediated by TNF- $\alpha$ [35]. Glutamate transporter expression in astrocytes is regulated by E2 through receptor GPR 30 and includes various ways of signals transfer [36]. The cAMP-PKA-dependent activation of CREB as well as the pathways of EGER-PIK3-NFkB has been established. The agonist of GPR30 G1 caused the increase of expression of mRNA and protein transporter GLT-1, accelerated glutamate capture by astrocytes in the primary culture. Allowing for the significance of excitotoxicity in pathogenesis of heavy neuro-degenerative diseases, GPR30 effects are very important in development of strategy of their therapy.

Estrogens prevent in vitro the toxical effect of 6-hydroxydophamine on PC12 cells [37]. It is shown that its effect results in translocation of the nuclear transcription factor Nur77 to cytoplasm with following apoptosis, and E2 inhibits translocation and prevents apoptosis of $\mathrm{PC} 12$ cells.

An important way of E2 influence on the brain may be its effect on the gene which codes protein similar to neuronal epidermal growth factor [38]. This human protein is coded by two genes: NELL1 and NELL2. The authors have shown that E2 transactivate gene NELL2 through receptors $\alpha$ and $\beta$, and this gene mediates protective effect of E2 on cultivated neuronal cells HiB5. When affected by neurotoxins ( $\beta$-amyloid or $\alpha$-amino-3-hydroxy-5-methyl4-isoxazolepropionate) estradiol increased distinctly survivability of cells. After adding estradiol (10 nM) the apoptosis caused by $\beta$-amyloid, was essentially suppressed, therewith this E2 effect depends on NELL2 [38].

Estrogens in vitro can protect cells of the hybrid line of motoneurons and neuroblastoma (VSC4.1) from injuring effect of tumor necrosis factor (TNF- $\alpha$ ), which plays an important role in pathogenesis of neurodegenerative diseases [39]. The authors have supposed that low doses of ER agonists may be used in therapy of brain injuries and neurodegenerative diseases.

Estrogens take great effect on activity of the cardiovascular system. They perform a protective effect, activating signal cascades of cell defense and increasing the expression of the heat shock proteins. In experiments estradiol protects the myocardium from ischemic lesions. The mechanism of protective 
effect of estrogens under lesions of cardiomyocytes, observed under hypoxia/oxygenation, has been analyzed [40]. Urocortin and its receptor (the receptor of corticotropin-releasing hormone 2 (CRHR2)) take part in this mechanism. E2 enforces the protective effect of urocortin under hypoxia/oxygenation and increases the expression of CRHR2 in cardiomyocytes. Consequently, the protective effect of E2 is determined by its influence on the urocortin receptor in cardiomyocytes.

The influence of estrogens on the vessels is diverse and includes quick vasodilatation, reduction of lesions of the vascular wall and inhibition of atherosclerosis development. The estrogen receptors and aromatase have been found in human blood vessels and endothelium [41, 42]. This enzyme ensures the local formation of estrogens from androgens and is broadly distributed in tissues.

Antiatherogenic effect of estrogens is preserved in mice with ER $\alpha$ gene knock-out [43] that is connected with ER $\beta$ availability in the endothelium. Acceleration of endothelium recovery after the lesion of its structure is one of the most important effects among numerous ones in the vessels. Estrogens control actin remodeling in the endothelial cells and development of specialized membrane structures such as raffles and pseudopodia, thus inducing the cell migration [44]. These phenomena depended on the activation of moesin - a protein regulaitor of actin.

Another important factor of the membrane remodeling and motion of cells is the change of the local adhesion complex. It is shown that in the presence of estradiol ER $\alpha$ forms the Gai/G $\beta$-dependent signal system which starts up the multiprotein complex where ER $\alpha, c-S r c$, PI3K and focal adhesion kinase (FAK) [45] interact. This mechanism is, probably, used in numerous processes where estrogens take a moduling part, such as remodeling of endotheliun, formation of neuronal bonds [46], growth of cancer [47], and development of atherosclerosis [48]. Akt activation by estrogens participates in the growth of axons and morphogenesis of neurons [49].

It is known that the myocardium contraction energy is provided by glucose and free fatty acids. It appeared that insulin and estrogens raise the content of glucose transporters GLUT4 и GLUT1 in the plasmatic membrane of myocytes [50]. Under joint effect of E2 and insulin the influence on GLUT4 is enhanced.

There are data indicating a possibility of direct influence of estrogens on the myocardium. Af- ter a single E2 administration to rats the activity of $\mathrm{Na}^{+}, \mathrm{K}^{+}$-ATPase, expression of $\alpha 1$-subunit and its phosphorylation considerably increased in the myocardium [51]. An increase of phosphorylation of protein kinase B (Akt) и ERK 1/2 was noted in experimental animals. A supposition is made on realization of E2 effect on $\mathrm{Na}^{+}, \mathrm{K}^{+}$-ATPase with participation of these systems.

Oncologists give great attention to estrogens. They investigate various aspects of estrogens' biology: their role in male and female cancerogenesis, analyze the use of the existing antiestrogens and search for new ones, study the mechanisms of resistance development to antiestrogens under cancer. The elucidation of pathways of transfer of cancerogenic signals in a cell as a target for tumor therapy is a new and rather promising trend [52]. Literature which clears up the importance of estrogens in oncogenesis is great and contradicting. The last to a large measure is related to existence of a variaty of receptor types and their splicing variants. The crosstalking of different systems of signals transfer is of great importance. It has been found that estrogens affect the expression of microRNA that changes signals realization. The analysis of litrature, dedicated to oncological aspects of estrogens activity, needs a separate publication, while we will touch some problems concerning just the tumors of the endocrinous system.

\section{Estrogens, metabolism, endocrinous glands}

All the organs and tissues of the endocrinous system belong to estrogen-sensitive tissues. The relation of estrogens and glands may be implemented at different levels, and a hypophyseal type of relation is supposedly the most known one. The formation of various tropic hormones in the hypophysis is in complex interrelations, and the change of estrogens content in the organism affects multiply the secretion of tropic compounds.

Epidemiological and prospective investigations point to a possible relation between estrogens and diabetes. ERs of both types are expressed in $\beta$-cells of Langerhans islands [53]. It is shown in experiments with physiological concentrations of estradiol that the concentration of insulin, its secretion and insulin gene expression increase in $\beta$-cells of incubated rat Langerhans islands, but the mass of $\beta$-cells does not change. The use of ER $\alpha$ and ER $\beta$ agonists as well as knock-out mice has shown that the effect of estrogens on the pancreas is realized through 
ER $\alpha$ and ERK 1/2 signal pathway is used [53]. The same authors have further shown the participation of ER $\beta$ in regulation of the pancreatic function [54]. E2 in physiological concentrations $(100 \mathrm{pM}-1 \mathrm{nM})$ decreases quickly activity of ATP-dependent potassium channels and intensifies insulin secretion by $\beta$-cells, stimulated by glucose. The given effect is mediated by ER $\beta$. E2 in high concentrations $(100 \mathrm{nM}-5 \mu \mathrm{M})$ increases insulin secretion through GPR30. The secretion of glucagon and oscillations of $\mathrm{Ca}^{2+}$ at low level of glucose are suppressed by E2.

Investigations on knock-out mice deprived of $\mathrm{ER} \alpha, \mathrm{ER} \beta$ or aromatase have shed additional light on this relation. It has been established that the resistance to insulin is developed in male mice with knock-out of the liver receptors ER $\alpha$, and realization of insulin signals in the liver is disturbed. This resistance is connected with the increase of content of proteins taking part in synthesis of fatty acids and triglycerols in the liver, the decrease of glycogen formation in the liver and increase of glucose formation under hyperinsulinemia [55].

It is known that the skeletal muscles and white adipose tissue are of great importance in glucose homeostasis. ER $\beta$ are mainly expressed in the skeletal muscles of mice, while ER $\alpha$ - in the white adipose tissue [56]. The knock-out of ER $\alpha$ gene causes an increase of expression of glucose transpoter GLUT4 and a fasting hypoglycaemia. The knock-out of ER $\alpha$ leads to a decrease of GLUT4 expression both in the skeletal muscles and in the white adipose tissue. Insulin resistance was observed in these mice. The difference of expression of glucose transporter in the muscles and adipose tissue under ER knock-out can explain contradictions in results of studying the effect of estrogens on glucose metabolism [56].

The development of insulin resistance, the increase of fasting blood glucose level in blood and under glucose load, as well as the increase of the level of triglycerols and cholesterol in blood following a meal are observed in mice with aromatase gene knock-out [57]. Examination of patients with aromatase deficit has confirmed interrelation between estrogens and homeostasis. Patients with deficit of aromatase or ER $\alpha$ function suffer from the disturbance of carbohydrate metabolism, insulin resistance, and hyperinsulinemia. The liver function and lipid profile disorder, and liver steatosis are observed in patients with aromatase deficit. Estrogen therapy under aromatase deficit leads to improvement of metabolic indices.
It is shown on the models of diabetes of type I and 2, that E2 introduction protects the pancreas from oxidative stress and toxical effect of amyloid, lypotoxicity [58] and apoptosis. In modern opinion all the types of receptors take part in realization of E2 effects in the pancreas; that is considered in the survey by Tiano [59]. ER $\alpha$ stimulates insulin biosynthesis activated by glucose and favors the survival of $\beta$-cells under the effect of proapoptotic factors. ER $\beta$ also intensifies insulin secretion activated by glucose. GPER protects $\beta$-cells from apoptosis and enhances insulin secretion, but does not affect its biosynthesis.

In vitro the selective ER $\beta$ agonist WAY200070 enhanced insulin secretion caused by glucose, human and mice Langerhans islands [60]. A single injection of WAY200070 to mice leads to elevation of insulin level in the blood and improves the result of the test with glucose load. A two-week administration increases the mass of $\beta$-cells in the pancreas and improves insulin sensitivity. WAY200070 improved regeneration of the mass of $\beta$-cells in mice with streptozotocin diabetes, as well as in $\mathrm{db} / \mathrm{db}$ mice.

Estradiol content increases essentially in the blood of rats with streptozotocin diabetes [61]. It is evident that the increase is the result of elevation of aromatase activity, caused by the increase of the enzyme expression established, in particular, in the kidneys and retina. ER $\alpha$ expression also increases in the kidneys.

Very interesting results have been obtained when analysing estrogens participation in preservation of the function of vessels under experimental diabetes [62]. Ovariectomy in rats with streptozotocin diabetes significantly decreases the expression of NOS3, Akt, PI3K and ER $\alpha$ in the aorta, and estradiol supplementation partially prevented these changes. E2 hampered a decrease of cGMP level and enhancement of iNOS expression, as well as an increase of production of NO metabolites. E2 decreased considerably the content of ROS in the aorta endothelium in ovariectomized rats with diabetes. ROS content also decreased under incubation (in the presence of E2) of endothelial cells from human aorta (line EA hy 926), treated with $\mathrm{H}_{2} \mathrm{O}_{2}$. Wortmanin (PI3K inhibitor), ER antagonist ICI 182780, and Akt inhibitor hamper positive effects of E2 on cultivated cells. The results obtained have shown that administration of E2 prevents down-regulation of the system $\mathrm{ER} \alpha / \mathrm{NOS} 3$ in the vessels of female rats with diabetes under deficit of endogenic hormones. 
The connection of estrogens with antioxidant system has long been noted. At present there exist the data that different average lifetime of males and females, which is also characteristic of numerous animal species, is determined by antioxidant effect of estrogen hormones. It has been shown that E2 regulates the antioxidant system of the transcription factor NRF2 through the PI3K/Akt pathway [62].

Medical investigations evidence, that pathology of the thyroid gland occurs more often in women largely during the period between puberty and menopause. Thyroid carcinoma appears in women much more often than in men. ER have been found both in the normal and tumor tissue of the thyroid gland [64], though there are works argueing the absence of ER $\alpha$ in the normal and tumor gland tissue [65]. The major publications about estrogen receptors in the thyroid gland tissue have been generalized in the survey by Rajoria [66]. Numerous investigations have demonstrated that E2 can accelerate cell proliferation of the thyroid gland [67]. There are data concerning the effect of E2 on the expression of sodium/iodide simporter gene and thyroglobulin gene [67]. Stem cells from the nodes of the thyroid gland express ER $\alpha$ and ER $\beta$, the expression of ER $\alpha$ surpasses considerably the level of expression in normal thyroid cells [68]. These data point to the participation of estrogens in the development of the goiter and in pathogenesis of nodule pathology.

The belief has been stated: estrogens take the opposite effect on the growth of cancer cells of the thyroid gland depending on the balance between receptor isoforms in the cells [69]. On this basis some authors consider the ER $\beta$ expression as a powerful differential-diagnostic criterion for differentiation of adenomas and follicular thyroid carcinomas [70]. The authors think that low ER $\beta$ expression is a bad prognostic index under the follicular thyroid carcinomas.

$E R \alpha$ and $E R \beta$ have been found in the tissue of human medullary thyroid carcinoma [71], but ER $\beta$ expression was observed more rarely. The role of these receptors has been analyzed on the cell culture of TT line of the medullary carcinoma of this gland. After ER-negative TT-cells were treated by the adenovirus vector carrying ER, this receptor functioned in the cells activating ERE-mediated gene response. However, the proliferation and apoptosis were realized differently, depending on the ER type. In the presence of estrogens ER $\alpha$ functioned as growth stimulator, while ER $\beta$ worked as growth inhibitor, independent of estrogen effect. It has been shown that for genes regulating apoptosis and cell cycle the transfer of estrogen signals may be performed on the pathway which does not use ERE [71]. The opinion is advanced that the modulation of these receptors and the influence on the transfer of their signals are potential trends of the therapy of thyroid carcinoma [72].

The effect of estrogens was studied in vitro on the cells of papillary carcinoma (KAT5), follicular carcinoma (FRO), and anaplastic carcinoma (ARO) from the thyroid gland [73]. Estradiol stimulated proliferation. ER $\alpha$ agonist stimulated growth and proliferation, increased expression of Bcl-2 and increased the level of phosphorylated ERK 1/2. This indicates the positive role of ERK $1 / 2$ in cell proliferation caused by E2. ER $\alpha$ knock-out inhibited the above effects of E2, while ER $\beta$ knock-out strengthened them [73]. Evidently, it is ER $\beta$ that takes part in the cell apoptosis of the thyrois gland. E2 and plant estrogen genistein caused proliferation of the cells of thyroid carcinoma of WRO, FRO and ARO lines. The actuation of genes regulating the cell cycle and proliferation of thyrois cells is mediated by GPR30 and MAP-kinase cascade [74]. Activation of growth of ARO cells having no ER $\alpha$ is additional corroboration of GPR30 participation in realization of estrogens' effect. The following sequence of events has been offered to implement E2 effect in the tumor cells of thyroid carcinoma: 1) quick activation of MAPK; 2) induction of c-fos and cyclines A and D1; 3) cell growth [74]. It has been established that E2 increases the expression of cyclines А и D1 in diffeent type tumor cells of the thyroid gland [74-76].

It is known that the level of peroxysome proliferator-activated receptor $\gamma$ (PPAR $\gamma$ ) is decresed in the cells of thyroid carcinoma. It appeared that PPAR $\gamma$ и ER $\alpha$ in terms of the function are in the feedback in the tumor cells [77]. Rosiglitazone PPAR $\gamma$ agonist - causes a decrease of ER $\alpha$ expression in the cells of papillary and anaplastic cancer. ER knockdown with microRNA resulted in the increase of expression of protein PPAR $\gamma$, ER expression increased under PPAR $\gamma$ blockade. Rosiglitazone prevented proliferative activity of $\mathrm{ER} \alpha$, but increased ER $\beta$ ability to decrease proliferation and migration of cancer cells. The obtained results evidence for the presence of negative feedback in ER $\alpha$ and PPAR $\gamma$. But ER $\beta$ and PPAR $\gamma$ jointly possess the inhibitory effect on proliferation and migration of cells of papillary thyroid cancer [77]. 
A possible role of estrogens in tumor metastatic propensity was investigated on cultivated cells of papillary cancer of the thyroid gland of BCPAP line [78]. It was found out that estradiol can increase the ability of these cells to metastatic propensity and invasion by estimates in vitro. The authors have established that the expression of E-cadherine in BCPAP cells decreases considerably under the effect of E2 and ER $\alpha$ agonist. Therewith the expression of vimentin and matrix metalloproteinase-9 (MMP-9) increased. In contrast, ER $\beta$ agonist caused a considerable increase of the expression of E-cadherine, while the expression of vimentin and MMP-9 lowred. These data evidence that in the thyroid gland ER subtypes play different role in carcinogenesis.

A decrease or absence of E-cadherine is shown in the cells of anaplastic cancer of the thyroid gland characterized by mesenchimal phenotype [79]. The authors have studied the effect of histone deacetylase inhibition on the expression of E-cadherine, cell migration and invasiveness. The investigations were conducted on three lines of cell cultures, primary culture and xenotransplants in mice. Inhibition of histone deacetylase induces the expression of Ecadherine. The complex E-cadherine/ $\beta$-catenine is adequately localized in the cell membrane, and the ability to cell migration and invasion decreases.

The estrogen receptors have been found in the adrenals as in the other endocrine glands. The estrogen receptors were also investigated in the human adrenal cortex and aldosteronomas [80]. It appeared that the basic estrogen receptors in these tissues are ER $\beta$ and GPER-1, respectively, though ER $\alpha$ is also expressed. After ER $\beta$ blockade by specific blocators, estradiol in vitro increased 5-7 times the expression of aldosterone synthase (CYP11B2) (EC 1.14.15.4) and formation of aldosterone by HAC 15 cells from human aldosteronoma. Agonist GPER-1 reproduced the given effect, but the antagonist GPER-1 and inhibitor of protein kinase A blocked the effect of E2. These data show that E2 through ER $\beta$ can inhibit aldosterone synthesis in human adrenals, but under ER $\beta$ blockade estradiol stimulates aldosterone formation through GPER-1 and protein kinase A.

But even before detecting the specific receptors it was established that the estrogen hormones activate synthesis of corticosteroid hormones

E2 stimulated formation of 11-hydroxycorticosteroids in the primary culture of adrenocortical cells of pigs. This effect depended on E2 concentration [81]. The incorporation of ${ }^{3} \mathrm{H}$-thymidine into DNA is enhanced in parallel. Hormones formation in the human adrenal slices increased more than 2.5 times in the presence of E2 [82]. The castration of male rats reduced considerably the content of 11-hydroxycorticosteroids in the blood plasma [83]. Three-day administration of E2 raised considerably the concentration of 11-hydroxycorticosteroids in the blood of both intact and orchiectomized animals.

Activation mechanism of adrenocortical function proved to be rather complex. Ovariectomy in rats caused a considerable decrease of specific binding of the labeled adrenocorticotropic hormone by the adrenal cortex microsomas [84]. Three-day E2 administration to ovariectomized rats raised ACTH binding up to the values in excess of the binding in control animals. The number of binding sites of highly affine and low affine receptors increased. The E2 administration to ovariectomized rats raised considerably the inclusion of labelled cholesterol into corticosterone - the principal adrenocortical hormone in rats [85]. An analogous but less expressed effect was traced on intact females.

It has long been established that the stimulating effect of ACTH on steroidogenesis in the adrenals is mediated by cAMP. Incubation of the human adrenal slices in the presence of E2 caused an increase of cAMP content, which began 1 hour after and continued to about the $4^{\text {th }}$ hour [86]. Maximum level of cAMP exceeded 7 times the initial indices [87]. Administration of E2 to castrated male rats raised almost 2 times the activity of cAMP-depended proteinkinase A (PKA) in cytosol fraction of the adrenal cortex and more than 1.6 times - in microsomal fraction [83]. Analogous changes were also observed in the adrenals of intact animals. In vitro E2 activated PKA in the microsomal fraction of human adrenal slices [87].

However PKA has not proved to be the only protein kinase activated by estrogens in this gland. The increase of activity of protein kinase C (PKC) has been established in the adrenal tissue of intact and castrated male rats which received E2 during three days [83]. Analogous results were obtained under incubation of human adrenal slices [83, 84]. The fact of the estrogens effect in the adrenal glands on protein kinases, activated by mitogens - MAPkinases, is of extreme interest. As a result of E2 administration to rats for three days the expression of ERK $1 / 2$, estimated with the help of western-blotting, increases in the adrenals 1.7 times [85]. The content of p38 and JNK did not change under these 
conditions. Determination of c-fos expression has shown a 1.8-fold dose-dependent increase of protein level under administration of $100 \mu \mathrm{g}$ of E2 [85, 86]. But the expression of c-jun did not change in these experiments.

When analyzing a direct effect of estrogens on formation of corticosteroids, we have studied the change of expression of cytochrome P450 scc (1.14.15.6) - the key steroidogenesis enzyme and steroidogenic acute regulatory protein (StAR). The incubation of human adrenal cortex slices in the presence of E2 elevated the expression level of mRNA of cytochrome P450scc and StAR in adrenocorticocytes by 38 and $79 \%$, respectively, as compared to control [90]. It is significant that after cholesterol transfer inside the adrenal mitochondria StAR molecule loses its ability of repeated transfers because of splitting-off the signal fragment. This determines a necessity of continuous synthesis of StAR.

There are numerous data on antiapoptotic effects of estrogens. The antiapoptotic effect of E2 in vitro is shown in the cells of skeletal muscles $\mathrm{C} 2 \mathrm{C} 12$ [91]. Cytoskeleton damages, picnotic and fragmented nuclei are found under treatment of these cells with $\mathrm{H}_{2} \mathrm{O}_{2}$. The preliminary treatment with E2 $\left(10^{-8} \mathrm{M}\right)$ prevents these changes of apoptotic character, but the inhibitors ERK and p38 block E2 effects. These results show that E2 supports the survival of cells of the skeletal muscles using the activation of ERK и p38 MAPK [91]. It has been established that E2 can activate ERK and then induce its translocation into mitochondria [92]. Therewith the activity of cytochrome oxidase complex IV increases. E2 prevents



Ways of estrogen effect realization in the adrenals. GPER - G-protein-coupled estrogen receptor; ER - nuclear receptor of estrogens; StAR - steroidogenic acute regulatory protein; P450scc - sidechain cleavage enzyme; MAPK - mitogen-activated proteinkinase; Bax - proapoptosis regulator; PKA - protein kinase A; $P K C$ - protein kinase C 
the collaps of mitochondrial potential caused by $\mathrm{H}_{2} \mathrm{O}_{2}$. Such is the mechanism of antiapoptotic effect of E2 in the authors' opinion.

Various effects of estrogens, connected with proliferation and apoptosis, are realized in the adrenal tissue: the content of DNA and RNA increases as a result of E2 administration to male rats [93]. Under the incubation of slices of conventionally normal tissue of human adrenal glands with E2, the level of mRNA of protein Bax decreased and apoptotic fragmentation of DNA was essentially inhibited [94]. These facts permit us to think that estrogens take the antiapoptotic effect in the adrenal tissue as in many other tissues. The main ways of estrogens effect on the adrenals are presented in the Figure.

Completing a brief survey of estrogens' biochemical effects it should be said that these compounds are universal participants of metabolism regulation processes. They display activity in practically all organs and systems both in norm and under pathology.

\section{БІОХІМІЧНІ ЕФЕКТИ ЕСТРОГЕНІВ У НЕРЕПРОДУКТИВНИХ ОРГАНАХ}

\section{О. С. Микоша, О. І. Ковзун, М. Д. Тронько}

ДУ «Інститут ендокринології та обміну речовин ім. В. П. Комісаренка НАМН України», Київ; e-mail: asmikosha@gmail.com

В огляді на основі даних літератури та власних досліджень охарактеризовано біохімічні процеси, які спричинюють естрогенні гормони в органах, не пов'язаних безпосередньо 3 розмноженням. За останнє десятиліття встановлено важливість цих сполук у регуляції фундаментальних біологічних процесів. Біохімічні механізми реалізації ефектів естрогенів можуть розглядатись як можливі ланки патогенезу низки захворювань та як мішені для їх терапії.

Кл ю ч о в і с лов в: естрогени, біохімічні механізми, нерепродуктивні органи, ендокринні залози, мозок, серцево-судинна система.

\section{БИОХИМИЧЕСКИЕ ЭФФЕКТЫ ЭСТРОГЕНОВ В НЕРЕПРОДУКТИВНЫХ ОРГАНАХ}

\author{
А. С. Микоша, Е. И. Ковзун, Н. Д. Тронько
}

ГУ «Институт эндокринологии и обмена веществ им. В. П. Комиссаренко НАМН Украины», Киев; e-mail: asmikosha@gmail.com

В обзоре на основании данных литературы и собственных исследований описаны биохимические процессы, вызываемые эстрогенными гормонами в органах, не связанных непосредственно с размножением. В последние десятилетия установлена важность этих соединений в регуляции фундаментальных биологических процессов. Биохимические механизмы реализации эффектов эстрогенов могут рассматриваться как возможные звенья патогенеза ряда заболеваний и как мишени для их терапии.

Ключевы е слова: эстрогены, биохимические механизмы, нерепродуктивные органы, эндокринные железы, мозг, сердечно-сосудистая система.

\section{References}

1. Siiteri P. K. Adipose tissue as a source of hormones. Am. J. Clin. Nutr. 1987;45:277-282.

2. Couse J. F., Mahato D., Eddy E. M., Korach K. S. Molecular mechanism of estrogen action in the male: insights from the estrogen receptor null mice. Reprod. Fertil. Develop. 2001;13(4):211219.

3. Green S., Walter P., Greene G., Krust A., Goffin C., Jensen E., Serace G., Waterfield M., Chambon P. Cloning of the human oestrogen receptor cDNA. J. Steroid. Biochem. 1986;24(1):77-83.

4. Kuiper G. G., Enmark E., Pelto-Huikko M., Nilsson S., Gustafsson J. A. Cloning of a novel receptor expressed in rat prostate and ovary. Proc. Natl. Acad. Sci. 1996;93(12):5925-5930. 
5. Paech K., Webb P., Kuiper G. G., Nilsson S., Gustafsson J. A., Kushner P. J., Scanlan T. S. Differential ligand activation of estrogen receptors $\mathrm{ER} \alpha$ and $\mathrm{ER} \beta$ at AP1 sites. Science. 1997;277(5331):1508-1510.

6. Enmark E., Pelto-Huikko M., Grandien K. A. J., Lagercrantz S., Lagercrantz J., Fried G., Nordenskjold M., Gustafsson, J. A. Human estrogen receptor $\beta$-gene structure, chromosomal localization, and expression pattern. J. Clin. Endocrin. Metab. 1997;82(12):42584265.

7. Kuiper G. G., Shughrue P. J., Merchenthaler I., Gustafsson J. $\AA$. The estrogen receptor $\beta$ subtype: a novel mediator of estrogen action in neuroendocrine systems. Front. Neuroendocrinol. 1998;19(4):253-286.

8. Millas I., Liquidato B. M. Estrogen receptors alpha and beta in non-target organs for hormone action: Review of the literature. Braz. J. Morphol. Sci. 2009;26(3-4):193-197.

9. Kumar V., Green S., Stack G., Berry M., Jin J. R., Chambon, P. Functional domains of the human estrogen receptor. Cell. 1987;51(6):941-951.

10. Tora L., White J., Brou C., Tasset D., Webster N., Scheer E., Chambon P. The human estrogen receptor has two independent nonacidic transcriptional activation functions. Cell. 1989;59(3):477-487.

11. Klein-Hitpaß L., Schorpp M., Wagner U., Ryffel G. U. An estrogen-responsive element derived from the $5^{\prime}$ flanking region of the Xenopus vitellogenin A2 gene functions in transfected human cells. Cell. 1986;46(7):10531061.

12. Gruber C. J., Gruber D. M., Gruber I. M., Wieser F., Gruber J. C. Anatomy of the estrogen response element. Trends Endocr. Metab. 2004;15(2):73-78.

13. Lonard D. M., O'Malley B. W. Expanding functional diversity of the coactivators. Trends Biochem. Sci. 2005; 0(3):126-132.

14. Khurana S., Chakraborty S., Zhao X., Liu Y., Guan D., Lam M., Huang W., Yang S., Kao H. Y. Identification of a novel LXXLL motif in $\alpha$-actinin 4 -spliced isoform that is critical for its interaction with estrogen receptor $\alpha$ and coactivators. J. Biol. Chem. 2012;287(42):3541835429.

15. O'Lone R., Frith M. C., Karlsson E. K., Hansen U. Genomic targets of nuclear estrogen receptors. Molec. Endocrinol. 2004; 18(8): 1859-1875.
16. Zhang Z., Maier B., Santen R. J., Song R. X. D. Membrane association of estrogen receptor $\alpha$ mediates estrogen effect on MAPK activation. Biochem. Biophys. Res. Commun. 2002;294(5):926-933.

17. Thomas P., Pang Y., Filardo E. J., Dong J. Identity of an estrogen membrane receptor coupled to a $\mathrm{G}$ protein in human breast cancer cells. Endocrinology. 2005;146(2):624-632.

18. Revankar C. M., Cimino D. F., Sklar L. A., Arterburn J. B., Prossnitz E. R. A transmembrane intracellular estrogen receptor mediates rapid cell signaling. Science. 2005;307(5715):16251630.

19. Boivin B., Vaniotis G., Allen B. G., Hebert T. E. $\mathrm{G}$ protein-coupled receptors in and on the cell nucleus: a new signaling paradigm? J. Recept. Signal Transduct. Res. 2008;28(1-2):15-28.

20. Prossnitz E. R., Barton M. Estrogen biology: new insights into GPER function and clinical opportunities. Mol. Cell. Endocrinol. 2014;389(1):71-83.

21. Srivastava D. P., Evans P. D. G-Protein oestrogen receptor 1: trials and tribulations of a membrane oestrogen receptor. J. Neuroendocrinol. 2013;25(11):1219-1230.

22. Li R., Cui J., Shen Y. Brain sex matters: estrogen in cognition and Alzheimer's disease. Mol. Cell. Endocrinol. 2014;389(1):13-21.

23. Janicki S. C., Schupf N. Hormonal influences on cognition and risk for Alzheimer's disease. Current Neurol. Neurosci. Rep. 2010;10(5):359366.

24. Hurn P. D., Macrae I. M. Estrogen as a neuroprotectant in stroke. J. Cereb. Blood Flow Metab. 2000;20(4):631-652.

25. Hurn P. D. Thomas Willis Award Lecture Sex, Stroke, and Innovation. Stroke 2014;45(12):37253729.

26. Suzuki S., Brown C. M., Cruz C. D. D., Yang E., Bridwell D. A., Wise P. M. Timing of estrogen therapy after ovariectomy dictates the efficacy of its neuroprotective and antiinflammatory actions. Proc. Nat. Acad. Sci. 2007;104(14):60136018.

27. Humphreys G. I., Ziegler Y. S., Nardulli A. M. $17 \beta$-Estradiol Modulates Gene Expression in the Female Mouse Cerebral Cortex. PLoS One. 2014;9(11):e111975.

28. Herrera J. L., Diaz M., Hernández-Fernaud J. R., Salido E., Alonso R., Fernández C., Morales A., 
Marin R. Voltage-dependent anion channel as a resident protein of lipid rafts: post-transductional regulation by estrogens and involvement in neuronal preservation against Alzheimer's disease. J. Neurochem. 2011;116(5):820-827.

29. Petrovska S., Dejanova B., Jurisic V. Estrogens: mechanisms of neuroprotective effects. $J$. Physiol. Biochem. 2012; 68(3): 455-460.

30. Lan Y. L., Zhao J., Li S. Update on the neuroprotective effect of estrogen receptor alpha against Alzheimer's disease. J. Alzheimer's Dis. 2015;43(4):1137-1148.

31. Marin R., Casanas V., Pérez J. A., Fabelo N., Fernandez C. E., Diaz M. Oestrogens as modulators of neuronal signalosomes and brain lipid homeostasis related to protection against neurodegeneration. J. Neuroendocrinol. 2013;25(11):1104-1115.

32. Fitzpatrick J. L., Mize A. L., Wade C. B., Harris J. A., Shapiro R. A., Dorsa, D. M. Estrogen-mediated neuroprotection against $\beta$-amyloid toxicity requires expression of estrogen receptor $\alpha$ or $\beta$ and activation of the MAPK pathway. J. Neurochem. 2002;82(3):674682.

33. Singer C. A., Rogers K. L., Dorsa, D. M. Modulation of Bcl-2 expression: a potential component of estrogen protection in NT2 neurons. Neuroreport. 1998;9(11):2565-2568.

34. Mize A. L., Shapiro R. A., Dorsa D. M. Estrogen receptor-mediated neuroprotection from oxidative stress requires activation of the mitogen-activated protein kinase pathway. Endocrinology. 2003;144(1):306-312.

35. Kark, P., Smit, K., Johnso, J., Lee E. Astrocyte-derived growth factors and estrogen neuroprotection: Role of transforming growth factor- $\alpha$ in estrogen-induced upregulation of glutamate transporters in astrocytes. Mol. Cell. Endocrinol. 2014;389(1):58-64.

36. Lee E., Sidoryk-Wêgrzynowicz M., Wang N., Webb A., Son D. S., Lee K., Aschne, M. GPR30 regulates glutamate transporter GLT-1 expression in rat primary astrocytes. J. Biol. Chem. 2012;287(32):26817-26828.

37. Renaud J., Chiasson K., Bournival J., Rouillard C., Martinoli M. G. 17 $\beta$-Estradiol Delays 6-OHDA-Induced Apoptosis by Acting on Nur77 Translocation from the Nucleus to the Cytoplasm. Neurotox. Res. 2014;25(1):124-134.

38. Choi E. J., Kim D. H., Kim J. G., Kim D. Y., Kim J. D., Seol O. J., Jeong C. S., Park J. W.,
Choi M. Y., Kang S. G., Costa M. E., Ojeda S. R., Lee B. J. Estrogen-dependent transcription of the NEL-like 2 (NELL2) gene and its role in protection from cell death. J. Biol. Chem. 2010;285(32):25074-25084.

39. Das A., Smith J. A., Gibson C., Varma A. K., Ray S. K. Banik N. L. Estrogen receptor agonists and estrogen attenuate TNF- $\alpha$-induced apoptosis in VSC4. 1 motoneurons. J. Endocrinol. 2011;208(2):171-182.

40. Cong B., Xu Y., Sheng H., Zhu X., Wang L., Zhao W., Tang Z., Lu J., Ni X. Cardioprotection of $17 \beta$-estradiol against hypoxia/reoxygenation in cardiomyocytes is partly through upregulation of CRH receptor type 2. Mol. Cell. Endocrinol. 2014;382(1):17-25.

41. Enmark E., Pelto-Huikko M., Grandien K. A. J., Lagercrantz S., Lagercrantz J., Fried G., Nordenskjold M., Gustafsson J. A. Human Estrogen Receptor $\beta$-Gene Structure, Chromosomal Localization, and Expression Pattern. J. Clin. Endocrinol. Metab. 1997;82(12):4258-4265.

42. Diano S., Horvath T. L., Mor G., Register T., Adams M., Harada N., Naftolin, F. Aromatase and estrogen receptor immunoreactivity in the coronary arteries of monkeys and human subjects. Menopause. 1999;6(1):21-28.

43. Iafrati M. D., Karas R. H., Aronovitz M., Kim S., Sullivan T. R., Lubahn D. B., O'Donnel T. F. jr., Korach K.S., Mendelsohn M. E. Estrogen inhibits the vascular injury response in estrogen receptor $\alpha$-deficient mice. Nature Med. 1997;3(5):545-548.

44. Simoncini T., Scorticati C., Mannella P., Fadiel A., Giretti M. S., Fu X. D., Baldacci C., Gaeibaldi S., Caruso A., Fornari L., Naftolin F., Genazzani, A. R. Estrogen receptor $\alpha$ interacts with $\mathrm{G} \alpha 13$ to drive actin remodeling and endothelial cell migration via the RhoA/Rho kinase/moesin pathway. Mol. Endocrinol. 2006;20(8):1756-1771.

45. Sanchez A. M., Flamini M. I., Zullino S., Gopal S., Genazzani A. R., Simoncini, T. Estrogen receptor- $\alpha$ promotes endothelial cell motility through focal adhesion kinase. Mol. Human Repr. 2011;17(4):219-226.

46. Sanchez A. M., Flamini M. I., Polak K., Palla G., Spina S., Mannella P., Genazzani A.D., Simoncini T. Actin cytoskeleton remodelling by sex steroids in neurones. J. Neuroendocrinol. 2012;24(1):195-201. 
47. Fu X. D., Goglia L., Sanchez A. M., Flamini M., Giretti M. S., Tosi V., Genazzani A.R., Simoncini T. Progesterone receptor enhances breast cancer cell motility and invasion via extranuclear activation of focal adhesion kinase. Endocr. Relat. Cancer. 2010;17(2):431-443.

48. Arnal J. F., Laurell H., Fontaine C., Billon A., Calippe B., Lenfant F., Gourdy P. Estrogen receptor actions on vascular biology and inflammation: implications in vascular pathophysiology. Climacteric. 2009;12(s1):12-17.

49. Varea O., Escoll M., Diez H., Garrido J. J., Wandosell F. Oestradiol signalling through the Akt-mTORC1-S6K1. Biochim. Biophys. Acta (BBA)-Molecular Cell Research. 2013;1833(5):1052-1064.

50. Tepavcevic S., Koricanac G., Zakula Z., Milosavljevic T., Stojiljkovic M., Isenovic E. R. Interaction between insulin and estradiol in regulation of cardiac glucose and free fatty acid transporters. Horm. Metab. Res. 2011;43(8):524530.

51. Obradovic M., Stewart A. J., Pitt S. J., LabudovicBorovic M., Sudar E., Petrovic V., Zafirovic S., Maravic-Stojkovic V., Vasic V., Isenovic E. R. In vivo effects of $17 \beta$-estradiol on cardiac $\mathrm{Na}^{+} /$ $\mathrm{K}^{+}$-ATPase expression and activity in rat heart. Mol. Cell. Endocrinol. 2014;388(1):58-68.

52. Renoir J. M., Marsaud V., Lazennec G. Estrogen receptor signaling as a target for novel breast cancer therapeutics. Biochem. Pharmacol. 2013;85(4):449-465.

53. Alonso-Magdalena P., Ropero A. B., Carrera M.P., Cederroth C. R., Baquie M., Gauthier B. R., Nef S., Stefani E., Nadal A. Pancreatic insulin content regulation by the estrogen receptor ER $\alpha$. PLoS One. 2008;3(4):e2069.

54. Ropero A. B., Pang Y., Alonso-Magdalena P., Thomas P., Nadal Á. Role of ER $\beta$ and GPR30 in the endocrine pancreas: a matter of estrogen dose. Steroids. 2012;77(10):951-958.

55. Zhu L., Martinez M. N., Emfinger C. H., Palmisano B. T., Stafford J. M. Estrogen signaling prevents diet-induced hepatic insulin resistance in male mice with obesity. Am. J. Physiol. Endocrinol. Metab. 2014;306(10):E1188-E1197.

56. Barros R. P., Gabbi C., Morani A., Warner M., Gustafsson J. A. Participation of ER $\alpha$ and ER $\beta$ in glucose homeostasis in skeletal muscle and white adipose tissue. Am. J. Physiol. Endocrinol. Metab. 2009;297(1):E124-E133.
57. Takeda K., Toda K., Saibara T., Nakagawa M., Saika K., Onishi T., Sugiura T., Shizuta Y. Progressive development of insulin resistance phenotype in male mice with complete aromatase (CYP19) deficiency. J. Endocrinol. 2003;176(2):237-246.

58. Tiano J. P., Delghingaro-Augusto V., Le May C., Liu S., Kaw M. K., Khuder S. S., Latour M. G., Bhatt S. A., Korach K. S., Najjar S. M., Prentki M., Mauvais-Jarvis F. Estrogen receptor activation reduces lipid synthesis in pancreatic islets and prevents $\beta$ cell failure in rodent models of type 2 diabetes. J. Clin. Invest. 2011;121(8):3331-3342.

59. Tiano J. P., Mauvais-Jarvis F. Importance of oestrogen receptors to preserve functional $\beta$-cell mass in diabetes. Nat. Rev. Endocrinol. 2012;8(6):342-351.

60. Alonso-Magdalena P., Ropero A. B., García-Arévalo M., Soriano S., Quesada I., Muhammed S. J., Salehi A., Gustafsson J-A., Nadal Á. Antidiabetic actions of an estrogen receptor $\beta$ selective agonist. Diabetes. 2013;62(6):2015-2025.

61. Prabhu A., Xu Q., Manigrasso M. B., Biswas M., Flynn E., Iliescu R., Lephart E. D., Maric C. Expression of aromatase, androgen and estrogen receptors in peripheral target tissues in diabetes. Steroids. 2010;75(11):779-787.

62. Han Y., Li X., Zhou S., Meng G., Xiao Y., Zhang W., Wang Z., Xie L., Liu Z., Lu H., Ji Y. 17ß-Estradiol Antagonizes the DownRegulation of ER $\alpha /$ NOS-3 Signaling in Vascular Endothelial Dysfunction of Female Diabetic Rats. PloS One. 2012;7(11):e50402.

63. Gorrini C., Gang B. P., Bassi C., Wakeham A., Baniasadi S. P., Hao Z., Li W. Y., Cescon D. W., Li Y-T., Molyneux S., Penrod N., Lupien M., Schmidt E. E., Stambolic V., Gauthier M. L., Mak T. W. Estrogen controls the survival of BRCA1-deficient cells via a PI3K-NRF2regulated pathway. Proc. Natl. Acad. Sci. USA. 2014;111(12):4472-4477.

64. Derwahl M., Nicula D. Estrogen and its role in thyroid cancer. Endocr. Relat. Cancer. 2014;21(5):T273-T283.

65. Vaiman M., Olevson Y., Sandbank J., Habler L., Zehavi S., Kessler A. Are estrogen receptors alpha detectable in normal and abnormal thyroid tissue? Eur. Arch. Oto-Rhino-Laryngol. 2010;267(11):1753-1757.

66. Rajoria S., Suriano R., George A. L., Shanmugam A., Jussim C., Shin E. J., Moscatello A. L., 
Geliebter J., Carpi A., Tiwari R. K. Estrogen activity as a preventive and therapeutic target in thyroid cancer. Biomed. Pharmacother. 2012;66(2):151-158.

67. Santin A. P., Furlanetto T. W. Role of estrogen in thyroid function and growth regulation. J. Thyroid Res. 2011;2011.

68. Xu S., Chen G., Peng W., Renko K., Derwahl M. Oestrogen action on thyroid progenitor cells: relevant for the pathogenesis of thyroid nodules? J. Endocrinol. 2013;218(1):125-133.

69. Thomas C., Gustafsson J. Å. The different roles of ER subtypes in cancer biology and therapy. Nat. Rev. Cancer. 2011;11(8):597-608.

70. Heikkilä A., Hagström J., Mäenpää H., Louhimo J., Siironen P., Heiskanen I., Haglund C., Arola J. Loss of estrogen receptor Beta expression in follicular thyroid carcinoma predicts poor outcome. Thyroid. 2013;23(4):456465.

71. Cho M. A., Lee M. K., Nam K. H., Chung W. Y., Park C. S., Lee J. H., Noh T., Yang W. I., Rhee Y., Lim S-K., Lee H. C., Lee E. J. Expression and role of estrogen receptor $\alpha$ and $\beta$ in medullary thyroid carcinoma: different roles in cancer growth and apoptosis. J. Endocrinol. 2007;195(2):255-263.

72. Chen G. G., Vlantis A. C., Zeng Q., van Hasselt . A. Regulation of cell growth by estrogen signaling and potential targets in thyroid cancer. Curr. Cancer Drug Targ. 2008;8(5):367-377.

73. Zeng Q., Chen G. G., Vlantis A. C., Van Hasselt C. A. Oestrogen mediates the growth of human thyroid carcinoma cells via an oestrogen receptor-ERK pathway. Cell Proliferation. 2007;40(6):921-935.

74. Vivacqua A., Bonofiglio D., Albanito L., Madeo A., Rago V., Carpino A., Musti A.M., Picard D., Ando S., Maggiolini M. 17ß-Estradiol, genistein, and 4-hydroxytamoxifen induce the proliferation of thyroid cancer cells through the G protein-coupled receptor GPR30. Mol. Pharmacol. 2006;70(4):1414-1423.

75. Manole D., Schildknecht B., Gosnell B., Adams E., Derwahl M. Estrogen Promotes Growth of Human Thyroid Tumor Cells by Different Molecular Mechanisms. J. Clin. Endocrinol. Metab. 2001;86(3):1072-1077.

76. Kumar A., Klinge C. M., Goldstein R. E. Estradiol-induced proliferation of papillary and follicular thyroid cancer cells is mediated by estrogen receptors $\alpha$ and $\beta$. Internat. J. Oncol. 2010;36(5):1067-1080.
77. Chu R., Hasselt A., Vlantis A. C., Ng E. K., Liu S. Y., Fan M. D., Ng S. K., Chan A. B., Liu Z., Li X. Y., Chen G. G. The cross-talk between estrogen receptor and peroxisome proliferatoractivated receptor gamma in thyroid cancer. Cancer. 2014;120(1):142-153.

78. Dong W., Zhang H., Li J., Guan H., He L., Wang Z., Shan Z., Teng W. Estrogen induces metastatic potential of papillary thyroid cancer cells through estrogen receptor $\alpha$ and $\beta$. Int. J. Endocrinol. 2013;2013:941568.

79. Catalano M. G., Fortunati N., Pugliese M., Marano F., Ortoleva L., Poli R., Asioli S., Bandino A., Palestini N., Grange C., Bussolati B., Boccuzzi G. Histone deacetylase inhibition modulates E-cadherin expression and suppresses migration and invasion of anaplastic thyroid cancer cells. J. Clin. Endocrinol. Metab. 2012;97(7):E1150-E1159.

80. Caroccia B., Seccia T. M., Campos A. G., Gioco F., Kuppusamy M., Ceolotto G., Guerzoni E., Simonato F., Mareso S., Lenzini L., Fassina A., Rossi G. P. GPER-1 and Estrogen Receptor- $\beta$ Ligands Modulate Aldosterone Synthesis. Endocrinology. 2014;155(11):4296-4304.

81. Kovzun O. I., Chelnakova I. S., Mikosha O. S. Effect of estradiol on 11-hydroxycorticosteroid synthesis and DNA labeling in a cell culture of adrenals of new-born piglets. $7^{\text {th }}$ Ukrainian Congress of Biochemistry (Abstracts), Part 2, Kyiv, 1997; 176-177. (In Ukrainian).

82. Kovzun O. I., Grinchenko E. N., Mikosha A. S. Activation of protein kinase $\mathrm{A}$ and protein kinase $\mathrm{C}$ by $17 \beta$-estradiol in human adrenal cortex in vitro. Ukr. Biokhim. Zhurn. 2005;77(2, spec. iss.):121.

83. Tronko M. D., Kovzun O. I., Grinchenko E. N., Mikosha A. S. Effects of estradiol on corticosteroids synthesis, activity of protein kinase $\mathrm{A}$ and $\mathrm{C}$ in the adrenal cortex of intact and orchiectomized rats. Fiziol. Zhurn. 2006;52(6):30-34. (In Ukrainian).

84. Sautin Yu. Yu., Kovzun H. I., Tronko N. D., Mikosha A. S. Stimulation of ACTH receptors by prolactin and estradiol. Endokrynologia. 1996;1(2):14-19. (In Ukrainian).

85. Kovzun O. I., Mikosha A. S. Influence of estradiol and ovariectomy on steroidogenesis and cholesterol content in the rat adrenal cortex. Endokrynologia. 2003;8(1):79-84. (In Ukrainian). 
86. Kovzun O. I. Involvement of protein kinases that are activated by mitogens, and transcription factor AP-1 in the transfer of corticotropin regulatory signal in rat adrenocorticocytes. Dopovidi NAN Ukrainy. 2006;(8):187-191. (In Ukrainian).

87. Grinchenko E. N., Kovzun E. I., Mikosha A. S. Effect of $17 \beta$-estradiol on content of cyclic nucleotides and protein kinases A and C activity in human adrenal cortex. Ukr Biokhim Zhurn. 2006;78(5):88-92. (In Russian).

88. Tronko M. D., Kovzun O. I., Kostyuchenko N. M., Grinchenko E. M., Lukashenya O. S., Mikosha A. S. Estrogens as a factor of adrenocortical function regulation: some molecular-genetic mechanisms and systems of signaling transduction. Pathologia. 2008;5(3):159. (In Ukrainian).

89. Tronko M. D., Mikosha O. S., Kovzun O. I., Pushkaryov V. M. Regulators of adrenocortical function. Kyiv: Doctor-Media Publishers, 2009. 244 P. (In Ukrainian).

90. Kovzun O. I., Kostuchenko N. N., Grinchenko E. M., Mikosha A. S. Effect of $17 \beta$-estradiol on the mRNA expression of steroidogenic acute regulatory protein StAR and cytochrome P450scc in human adrenal cortex. Endokrynologia. 2009;14(1):120-125. (In Ukrainian).

91. Ronda A. C., Vasconsuelo A., Boland R. Extracellular-regulated kinase and p38 mitogenactivated protein kinases are involved in the antiapoptotic action of $17 \beta$-estradiol in skeletal muscle cells. J. Endocrinol. 2010;206(2):235-246

92. Ronda A. C., Vasconsuelo A., Boland R. 17 $\beta$-Estradiol Protects Mitochondrial Functions through Extracellular-Signal-Regulated Kinase in C2C12 Muscle Cells. Cell. Physiol. Biochem. 2013;32(4):1011-1023.

93. Kovzun O. I., Grinchenko E. M., Kalynska L. M., Mikosha A. S. Effects of estradiol benzoate in vivo on RNA and DNA content in the adrenal cortex, pituitary and hypothalamus of male rats. Endokrynologia. 2006;11(2):213-218. (In Ukrainian).

94. Tronko M. D., Kovzun O. I., Grinchenko E. N., Mikosha A. S. Effect of $17 \beta$-estradiol on mRNA expression of proapoptotic protein Bax and DNA fragmentation level in human adrenal cortex. Ukr. Biokhim. Zhurn. 2009;81(2):80-84. (In Ukrainian).

Received 27.05.2015 